\title{
ORIENTAÇÕES SOBRE O ENSINO DA ESCRITA NA REVISTA DO ENSINO/RS: REPERCUSSÕES DA OBRA DE ORMINDA MARQUES (1930-1960) ${ }^{1}$
}

DOI: http://dx.doi.org/10.1590/2236-3459/54440

\author{
Carolina Monteiro \\ Universidade Federal do Rio Grande do Sul, Brasil.
}

Resumo

Pelo texto objetiva-se problematizar em que medida a obra de Orminda Marques, tomada como um marco histórico do ensino da escrita no Brasil e como instrumento de divulgação dos preceitos da Escola Nova no país, persistiu, por mais de três décadas após sua publicação, como referência para a formação de professores. Tomando como principal documento o livro A escrita na escola primária (1936), de autoria da educadora, são analisados artigos sobre o ensino da escrita publicados na Revista do Ensino/RS que fazem referência à obra. Compreende-se que as aproximações identificadas consistem em repercussões da obra da autora no tempo a partir da reflexão sobre os conceitos de produção, circulação e apropriação do texto, propostos pelo historiador francês Roger Chartier.

Palavras-chave: história da educação, ensino da escrita, Orminda Marques, formação de professores, Revista do Ensino/RS.

\section{ORIENTATIONS ON THE TEACHING OF WRITING IN THE REVISTA DO ENSINO/RS: REPERCUSSIONS OF THE WORK OF ORMINDA MARQUES (1930-1960)}

\begin{abstract}
The text aims to problematize to what extent the work of Orminda Marques, taken as a landmark of the teaching of writing in Brazil and as a dissemination tool of the precepts of the New School in the country, persisted for more than three decades after its publication, as reference to teacher qualification. Taking the book $A$ escrita na escola primária (1936), written by the educator, the text analyzes articles about the teaching of writing published in the Revista do Ensino/RS that make reference to the work. It is understood that the identified approaches consist in repercussions of the
\end{abstract}

${ }^{1}$ Pesquisa desenvolvida no âmbito do curso de mestrado em Educação da Universidade Federal do Rio Grande do Sul com recursos financeiros da Capes. A primeira versão foi apresentada na $36^{a}$ reunião nacional da Anped, realizada em Goiânia/GO, entre os dias 29 de setembro e 2 de outubro de 2013. 
work of the author in time from the reflection on the concepts of production, circulation and appropriation of the text proposed by the french historian Roger Chartier.

Key-words: history of education, teaching of writing, Orminda Marques, teacher qualification, Revista do Ensino/RS.

\section{ORIENTACIONES SOBRE LA ENSEÑANZA DE LA ESCRITURA EN LA REVISTA DO ENSINO/RS: REPERCUSIONES DEL TRABAJO DE ORMINDA MARQUES (1930-1960)}

\section{Resumen}

El propósito del texto es cuestionar hasta qué punto el trabajo de Orminda Marques, tomado como un punto de referencia de la enseñanza de la escritura en Brasil y como una herramienta de difusión de los preceptos de la Nueva Escuela en el país, persistió durante más de tres décadas después de su publicación, como referencia a la formación de profesores. Tomando como documento principal el libro $A$ escrita na escola primária (1936), escrito por el educador, se analizan los artículos sobre la enseñanza de la escritura publicados en la Revista do Ensino/RS que se refieren a la obra. Se entiende que los enfoques identificados consisten en repercusiones del trabajo del autor en el tiempo desde la reflexión sobre los conceptos de producción, circulación y apropiación del texto propuestos por el historiador francés Roger Chartier.

Palabras-clave: historia de la educación, enseñanza de la escritura, Orminda Marques, formación de profesores, Revista do Ensino/RS.

\section{ORIENTATIONS SUR L'ENSEIGNEMENT DE L'ÉCRITURE DANS LA REVISTA DO ENSINO/RS: REPERCUSSIONS DE L'OEUVRE DE ORMINDA MARQUES (1930-1960)}

\section{Résumé}

Le texte vise à examiner dans quelle mesure l'oeuvre de Orminda Marques, pris comme un point de repère de l'enseignement de l'écriture au Brésil et comme un outil de diffusion des préceptes de la Nouvelle École dans le pays, a persisté pendant plus de trois décennies après sa publication comme référence pour la formation des enseignants. Prenant comme document principal le livre $A$ escrita na escola primária (1936), écrite par l'éducateur, sont analysés articles sur l'enseignement de l'écriture publié dans le Revista do Ensino/RS qui se réfèrent au travail. II est entendu que les approches identifiées consistent en répercussions de l'oeuvre de l'auter dans le temps à partir de la réflexion sur les concepts de production, circulation et appropriation de texte proposés par l'historien français Roger Chartier.

Mots-clé: histoire de l'éducation, enseignement de l'écriture, Orminda Marques, formation des enseignants, Revista do Ensino/RS. 


\section{Introdução}

nserida no contexto da reforma da instrução pública do Rio de Janeiro, que agregava os princípios do movimento da Escola Nova dos anos 1930, a professora Orminda

Marques, então diretora da Escola Primária do Instituto de Educação do Distrito Federal (RJ), dedicou-se à realização de um estudo da boa escrita, entre os anos de $1933 \mathrm{e}$ 1936, ao identificar uma espécie de decadência no nível de escrita dos alunos. Tal estudo deu origem ao livro $A$ escrita na escola primária (1936), tomado como documento central neste estudo.

O propósito é identificar repercussões em diferentes impressos em circulação no país, especialmente nos anos 1930-1960, das proposições apresentadas neste livro de Orminda Marques. Optou-se em focalizar artigos sobre o ensino da escrita publicados na Revista do Ensino/RS que se valem dessa obra como referência central.

A Revista do Ensino/RS, publicação vinculada à Secretaria de Educação e Cultura do Rio Grande do Sul - SEC/RS -, representa um importante meio de propagação de ideias e modelos pedagógicos, o que justifica a relevância desse documento para um estudo que examina as repercussões das proposições de Orminda Marques, em especial no Rio Grande do Sul. Segundo Bastos (2005),

a Revista do Ensino constitui-se como uma tribuna de diferentes especialistas, que expressaram suas ideias e pensamentos refletindo o movimento de ideias em nível regional e nacional. Ao mesmo tempo, pretendeu ser um veículo de divulgação da política educacional, procurando mobilizar e integrar o professor no projeto de reconstrução nacional e renovação educacional, pela normatização e homogeneização de determinados princípios e práticas escolares. (p. 114)

Faz-se necessário assinalar que, inspirado em estudos de historiadores da cultura escrita, em especial de Roger Chartier, este estudo analisa tais repercussões a partir de três conceitos centrais: produção, circulação e apropriação. Sob esse aspecto é possível compreender o contexto e as condições que levaram à publicação da obra, o que auxilia a identificar as razões pelas quais as ideias da autora, seu livro e demais publicações circularam entre o professorado e como foram apropriados para a produção de novos materiais de orientação para o ensino da escrita.

\section{A escrita na escola primária: contexto e produção da obra de Orminda Marques}

Com a finalidade de divulgação dos preceitos da educação renovada o livro $A$ escrita na escola primária foi publicado pela primeira vez em 1936, com uma segunda edição em 1950. 
Imagem 1 -

Capa do livro A escrita na escola primária de Orminda Marques, 1936.

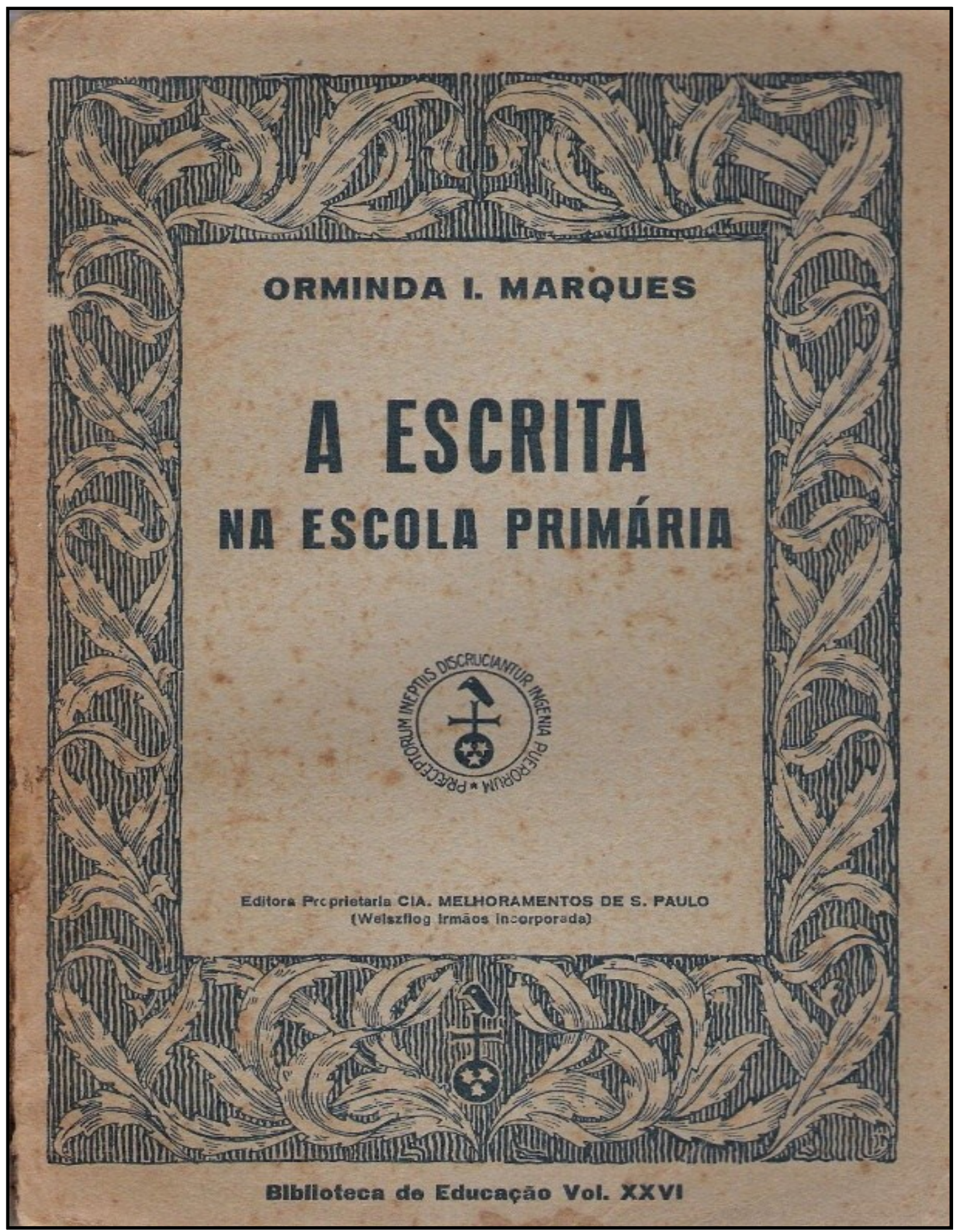


A obra integrou a coleção Bibliotheca de Educação, organizada por Manuel Bergström Lourenço Filho, incentivador do trabalho de Orminda, que assinou o prefácio do livro, sob o título $A$ escrita e a escola renovada, no qual ele apresenta uma breve discussão sobre a mudança de concepção do ensino da escrita a partir do escolanovismo e, em seguida, destaca o trabalho desenvolvido por Orminda Marques na elaboração do livro, que teve por base esses novos preceitos para a educação. Sobre isso Lourenço Filho ainda afirma que a autora tinha uma "grande vantagem sobre outros estudiosos do assunto: a de não ser calígrafa. Sua atenção por isso mesmo, não esteve dirigida tão somente para o produto da aprendizagem, mas para o aprendiz, para a criança" (Lourenço Filho, 1936, p. 5). O educador demonstra, assim, a convicção da autora nos postulados do escolanovismo, em especial a centralidade da criança no ensino.

Com apenas duas páginas a seção seguinte da primeira edição do livro foi intitulada Advertência, na qual a autora apresenta o estudo e agradece àqueles que contribuíram para o seu desenvolvimento. Já na Apresentação destacam-se os seguintes dados: o período de três anos de experimentação no Instituto de Educação do Distrito Federal (RJ), a fundamentação em outros estudos sobre o ensino da escrita e a sistematização de um plano para este ensino na escola primária.

Vale ressaltar que nesta obra a autora compara a escola tradicional, que trabalhava a leitura, a escrita e o cálculo sem sentido para a criança, com a escola nova, que prioriza o caráter funcional dessas habilidades. Segundo a autora, a partir dos ideais escolanovistas, há a mudança dos objetivos do ensino da caligrafia, pois "exige-se da escola, para uma vida mais moderna, escrita também mais moderna" (Marques, 1936, p. 18). Concebia essa escrita moderna como escrita clara, legível e feita rapidamente. A autora ainda contrasta esses dois momentos do ensino da escrita ao afirmar que, antes, para aprender, bastava repetir, ao passo que no momento em que ela se encontrava refletindo sobre o ensino da escrita eram cruciais a motivação, pela funcionalidade da escrita, ou seja, as propostas deveriam ter uma finalidade significativa para as crianças como forma de motivá-las, além da consideração dos interesses naturais das crianças, pelo jogo, brincadeiras, definição de objetivos e de projetos de trabalho.

A partir de seus experimentos no Instituto de Educação do Distrito Federal, a diretora Orminda Marques apresenta a caligrafia muscular como o processo que parece atender de modo mais completo às exigências dos objetivos por ela definidos para a aprendizagem da escrita. Em sua perspectiva, tal processo, baseado nos princípios gerais da psicologia da aprendizagem e da fisiologia do trabalho muscular, tinha relação direta com o ritmo.

Orminda Marques incluiu em seu livro um programa para o ensino da escrita, acompanhado de orientações para cada ano, exemplos de exercícios e sugestões de atividades. Para o primeiro dos cinco anos em que o aprendizado da escrita se efetivava na época a educadora propunha que a escrita deveria se desenvolver pela simples imitação, não sendo desligada da leitura. Além disso, destacava a importância dos exercícios preparatórios para a escrita como forma de aprimorar a coordenação motora. Um exemplo encontra-se a seguir. 
Figura 2 -

Exercícios preparatórios.

166

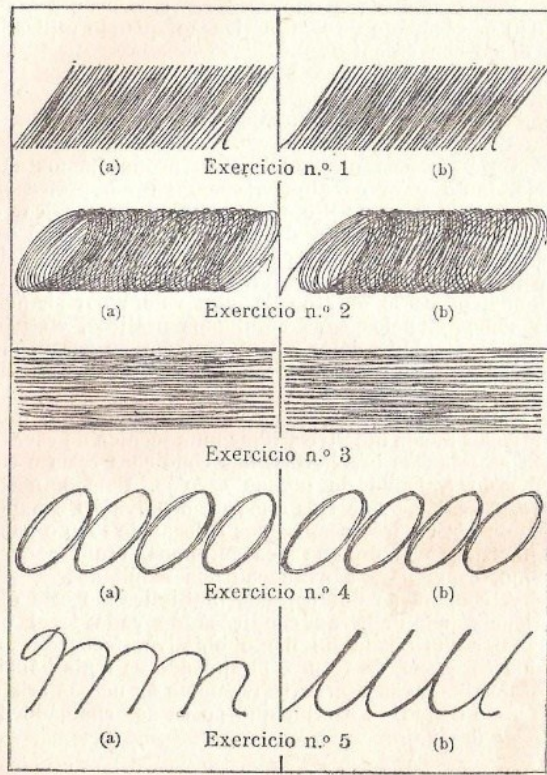

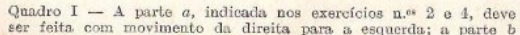
ser feita, com movimento da direita para is esquerda; a parte b
dos mesmos exerćcios deve ser feita no sentido inverso.
A ESCRITA NA ESCOLA PRIMÁRIA

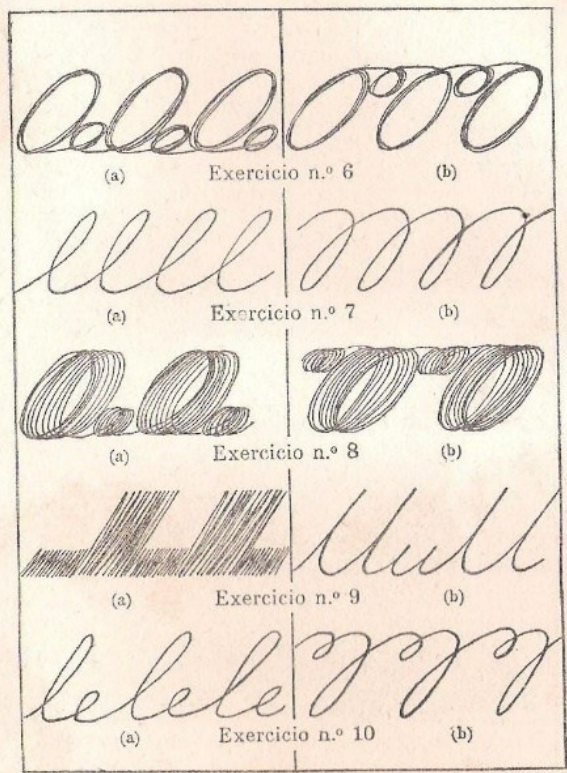

Quadro II - 1 parte a, indicada nos exercícios 6 e 8 , deve
ser feita com movimento da direita para a esquerda; a parto b

Fonte: Marques, 1936, p. 166-167.

O tipo de exercício utilizado para o treino da habilidade motora, que se mantinha até o terceiro ano, levava à construção de desenhos simples, bastante próximos do universo infantil, como o traçado de barcos, coelhos, peixes, gatos. Uma técnica para a realização de tais exercícios era a utilização de canções, palmas e contagem para marcar o ritmo da escrita, de acordo com os interesses e necessidades de cada ano. Segundo Braga (2008) Orminda recomendava esta prática porque acreditava que "a música contribuiria para que a criança incorporasse o ritmo do pulso e, pela repetição do ritmo, ela chegaria ao automatismo, ao controle do movimento e, consequentemente, à velocidade" (p. 143). Como exemplo da atividade descrita, segue-se um desenho sugerido no livro de Orminda, acompanhado de uma música. 
Figura 3 -

Exercício para o $1^{\circ}$ ano.

\section{O meu lapis vai rodando, Vai rodando, vai rodando, Que será que você viu? Olhe só... é o Piú... Piú...}

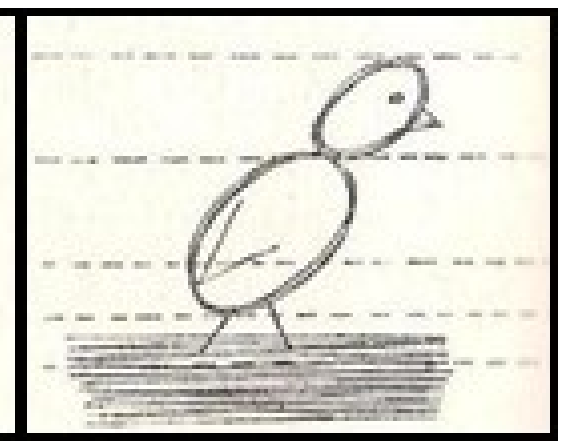

Fonte: Marques, 1936, p. 100

Ao final do primeiro ano a criança iniciava a formação das letras, ainda sem preocupação com a perfeição absoluta. Nesse momento as letras deveriam ser dividas em grupos, para estudo de acordo com sua forma e traçado, como apresentado na figura abaixo. Segundo a autora ainda não haveria preocupação com a velocidade, que deveria ser desenvolvida naturalmente, com a qualidade da escrita.

Figura 4 -

Grupos para iniciação do traçado das letras.

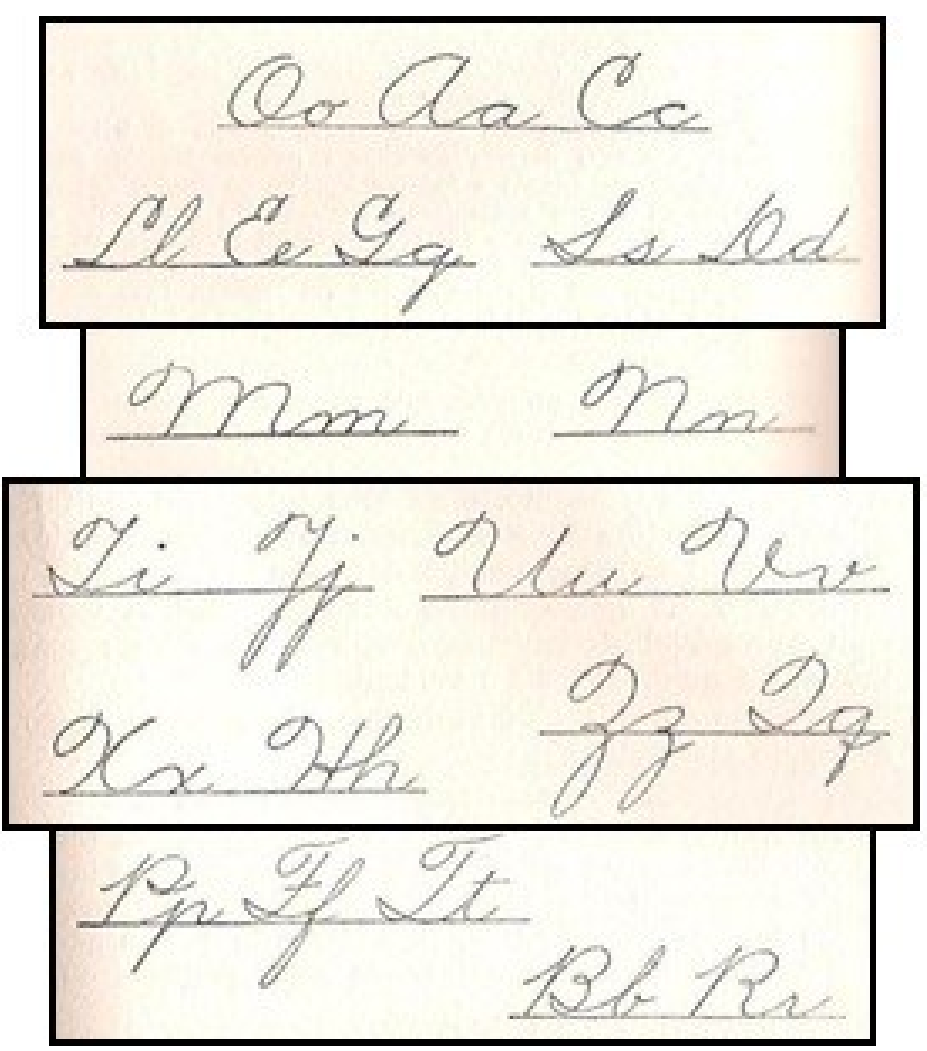

Fonte: Marques, 1936, p. 104-105. 
Ao longo do segundo ano o aluno deveria adquirir boa atitude com os trabalhos escritos no que diz respeito à sua apresentação, desenvolver letra de tamanho normal, aperfeiçoar a forma e obter uniformidade de inclinação e alinhamento, além de maior desembaraço de movimentos e leveza de traços. O exemplo abaixo consiste em um exercício proposto para o segundo ano.

Figura 5 -

Exercício para o $2^{\circ}$ ano.

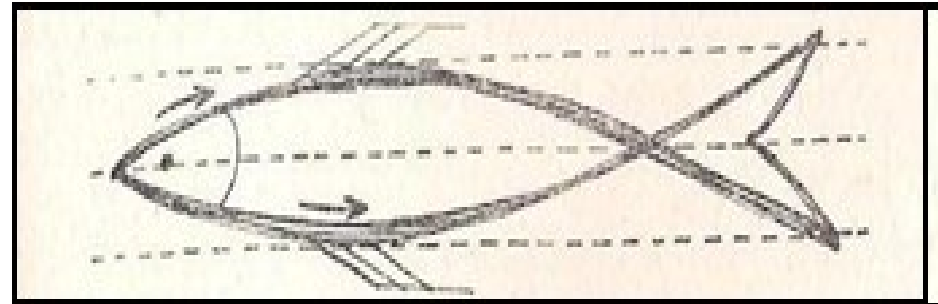

Corre, lapis, bem depressa,

No papel a desenhar:

Pois um lindo peixe espada,

Eu acabo de pescar.

Fonte: Marques, 1936, p. 109.

No terceiro ano, assim como no segundo, a criança desenvolveria boa atitude para com os trabalhos escritos, complementaria seu estágio de desenvolvimento em relação à forma fundamental das letras no que diz respeito à regularidade em tamanho, inclinação e alinhamento, desenvolvendo posição adequada do corpo, da caneta e da inclinação do papel. A partir da segunda fase deste período era recomendado o uso da pena. Além disso o aluno deveria habituar-se às boas normas de apresentação do trabalho escrito com relação às margens, parágrafos e cabeçalho. $O$ aluno também deveria escrever com desembaraço $e$ leveza de traços. A seguir, exemplo de exercício sugerido pela autora para o terceiro ano.

Figura 6 -

Exercício para o $3^{\circ}$ ano.

Minha pena está girando,

Está girando sem parar.

Roda, roda, direitinho

P'ra a cegonha vir formar.

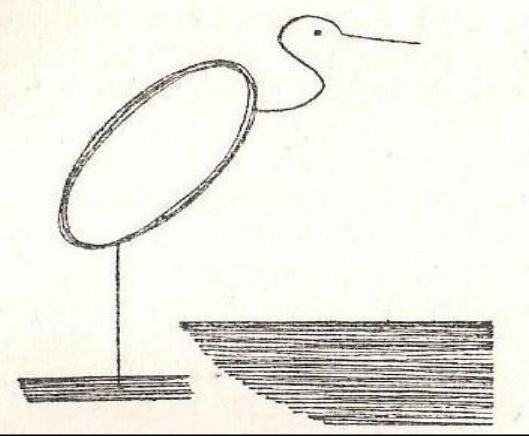

Fonte: Marques, 1936, p. 118. 
No quarto e no quinto ano a técnica deveria alcançar o mais alto nível de aperfeiçoamento possível, obtendo maior leveza e velocidade da escrita, sem prejuízo das qualidades já obtidas, em especial a legibilidade, tendo maior controle, eficiência e economia de movimentos. Somente após percorrer esses momentos o aluno poderia dar ao traçado um estilo pessoal, característica valorizada por Orminda e proporcionada pela metodologia do sistema muscular, uma vez que o processo de aquisição da escrita não se limitava à imitação de um modelo específico. Importa destacar que a autora propunha em sua obra, também, atividades dinâmicas e coletivas de elaboração de convites, cartazes e dramatizações, como a exemplificada abaixo.

Figura 7 -

Plano para dramatização para o $4^{\circ}$ e $5^{\circ}$ ano.

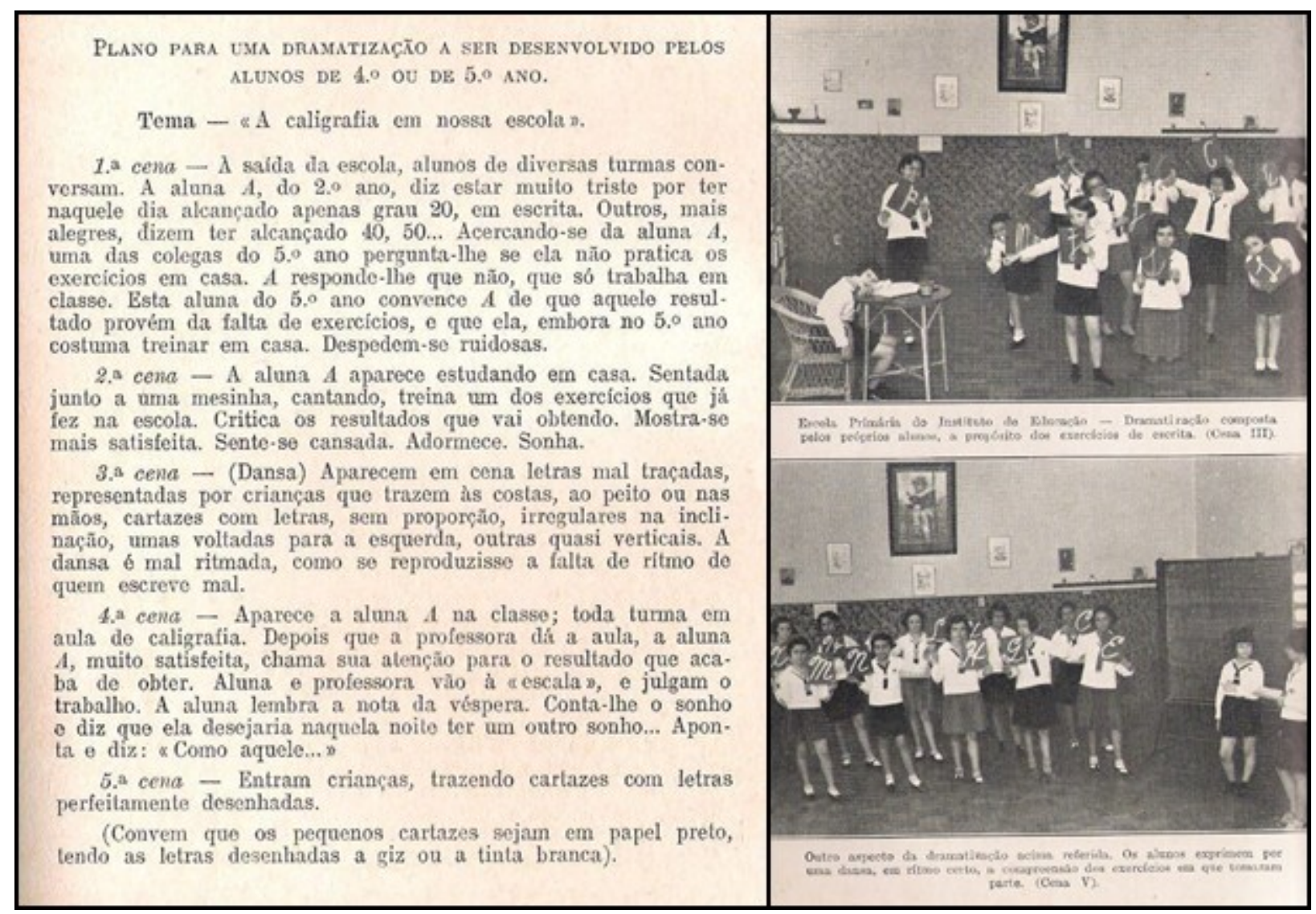

Fonte: Marques, 1936, p. 149.

No livro, Orminda ainda reservou um capítulo para expor diferentes formas de verificar o rendimento do ensino da escrita, tais como: pela medida da qualidade, da medida da velocidade e da medida conjunta da qualidade e da velocidade. Propôs que se organizasse uma escala provisória em cada classe, com escritas colhidas dos alunos e dispostas em ordem ascendente de qualidade, a ser exposta em uma folha de cartolina na sala de aula.

Além desse recurso, sugeria a aplicação de pequenos testes para apurar a velocidade: contar o número de letras escritas de um trecho e dividir o total por dois, a qualidade: 
escrever um trecho o melhor possível em tempo indeterminado e comparar com a classe, e a velocidade em combinação com a qualidade: escrever em tempo determinado tão depressa quanto possível, mas tão bem quanto possível. A educadora afirmava que, frequentemente, havia perda da qualidade com a escrita muito rápida, mas que cada indivíduo poderia chegar a escrever bem e rápido em tipo normal e pessoal de letra:

É certo que não deve haver insistência em relação à rapidez da escrita, em os primeiros anos da escola primária, antes do aluno ter conquistado a formação do hábito de escrever. A rapidez no escrever deve ser moderadamente desenvolvida enquanto são firmados os fatores de que essencialmente depende sua qualidade: ritmo dos movimentos, inclinação e tamanho das letras, ligação destas e de seus elementos. A posição correta do corpo e o uso de material adequado importam também na rapidez. (Marques, 1936, p. 158)

Ao analisar seu contexto de produção é possível constatar que o livro escrito por Orminda Marques, a partir de minucioso estudo empírico desenvolvido pela autora junto às crianças das classes de ensino primário no Instituto de Educação do Distrito Federal, constitui um manual pedagógico para o ensino da escrita, especificamente da bela letra, no sentido moderno que assumiu frente às necessidades da sociedade em transformação. $O$ trabalho apresenta-se fundamentado teoricamente, demonstrando atenção às preocupações da época no campo pedagógico e o engajamento da autora nesse sentido, que se deve, também, a sua atuação na formação de professores na Escola de Educação. Contou com a aprovação de Lourenço Filho, que elegeu este texto para integrar, como livro, a coleção Bibliotheca de Educação, alçando o estudo de Orminda como uma obra a constar dentre aquelas imprescindíveis à formação de professores, âmbito no qual a escrita apresentou-se como aprendizado imperativo da educação escolar.

Diversos estudos se ocuparam dos preceitos de Orminda para o ensino da escrita, bem como da adoção de suas propostas em práticas escolares do período. $O$ estudo aqui apresentado, contudo, dirige-se a examinar, no contexto de um conjunto documental específico, como o livro de Orminda fundamentou a produção de textos e impressos pedagógicos dirigidos a professores, mesmo depois de decorridos cerca de 20 anos da publicação da primeira edição d'A escrita na escola primária (1936).

\section{Revista do Ensino/RS: circulação e apropriação do texto}

A Revista do Ensino/RS consiste em um importante documento da história da educação no Rio Grande do Sul por seu papel na propagação do ideário da Escola Nova no Estado. Destinado ao professorado o periódico tinha como característica a publicação de artigos visando à divulgação de pensamentos e projetos desenvolvidos nesse âmbito para a formação de professores. 
Segundo Maria Helena C. Bastos (2005), "no elenco de artigos da Revista do Ensino voltados ao preparo intelectual e técnico do professor, há um conjunto cuja finalidade era prescrever modos de atuação didática do professor - artigos que prescreviam minudentemente o quê ensinar e como ensinar" (p. 239). Entre os temas dessas orientações se encontra a linguagem e, nesse âmbito, o foco de interesse deste trabalho: a escrita e a caligrafia.

Foram localizados, considerando o recorte temporal deste estudo - anos 1930 a 1960 -, quatro artigos que fazem referência ao trabalho desenvolvido por Orminda Marques, seja no corpo do texto, seja na inclusão de sua obra como bibliografia dos artigos publicados.

No artigo Preparando para ler (1956), de Arlette Pinto de Oliveira e Silva, assistente de Metodologia da Linguagem na Escola Guatemala (DF), que consta no número 36 da Revista do Ensino/RS, o ensino da escrita está destacado no subtítulo Exercícios caligráficos baseados no ritmo. Ao final do artigo identifica-se a indicação do livro $A$ escrita na escola primária, de Orminda Marques, sob a forma de bibliografia aconselhável.

O objetivo do texto é apontar sugestões de exercícios caligráficos ritmados, que devem corresponder ao tempo máximo de 20 minutos de duração. Há, nas proposições, a valorização do jogo e da brincadeira, além de atividades dramatizadas. O roteiro do trabalho segue a condução do professor, inicialmente com a apresentação da situação e memorização da quadra pelo canto. Em seguida alunos e professores devem fazer a marcação do ritmo com palmas. Após isso recomenda que o professor faça o movimento no ar e de costas para as crianças, à frente delas, para que possam reproduzi-lo igualmente. $O$ passo seguinte deve ser o traçado no quadro, feito pelo professor, do movimento de escrita e depois o traçado pelos alunos, também no quadro, finalizando com o traçado, em conjunto, no papel. A autora destaca, em nota no corpo do texto, uma referência à Orminda: "para maiores detalhes sobre a aplicação do ritmo ao movimento caligráfico será de interesse consultar o livro de autoria da professora Orminda Marques e intitulado: A escrita na Escola Primária" (SILVA, 1956, p. 16).

Silva classifica os três tipos de movimentos caligráficos: movimento do pêndulo, movimento de subida e descida e traçado de ovais, conforme figura a seguir. 
Figura 8 -

Movimentos caligráficos.

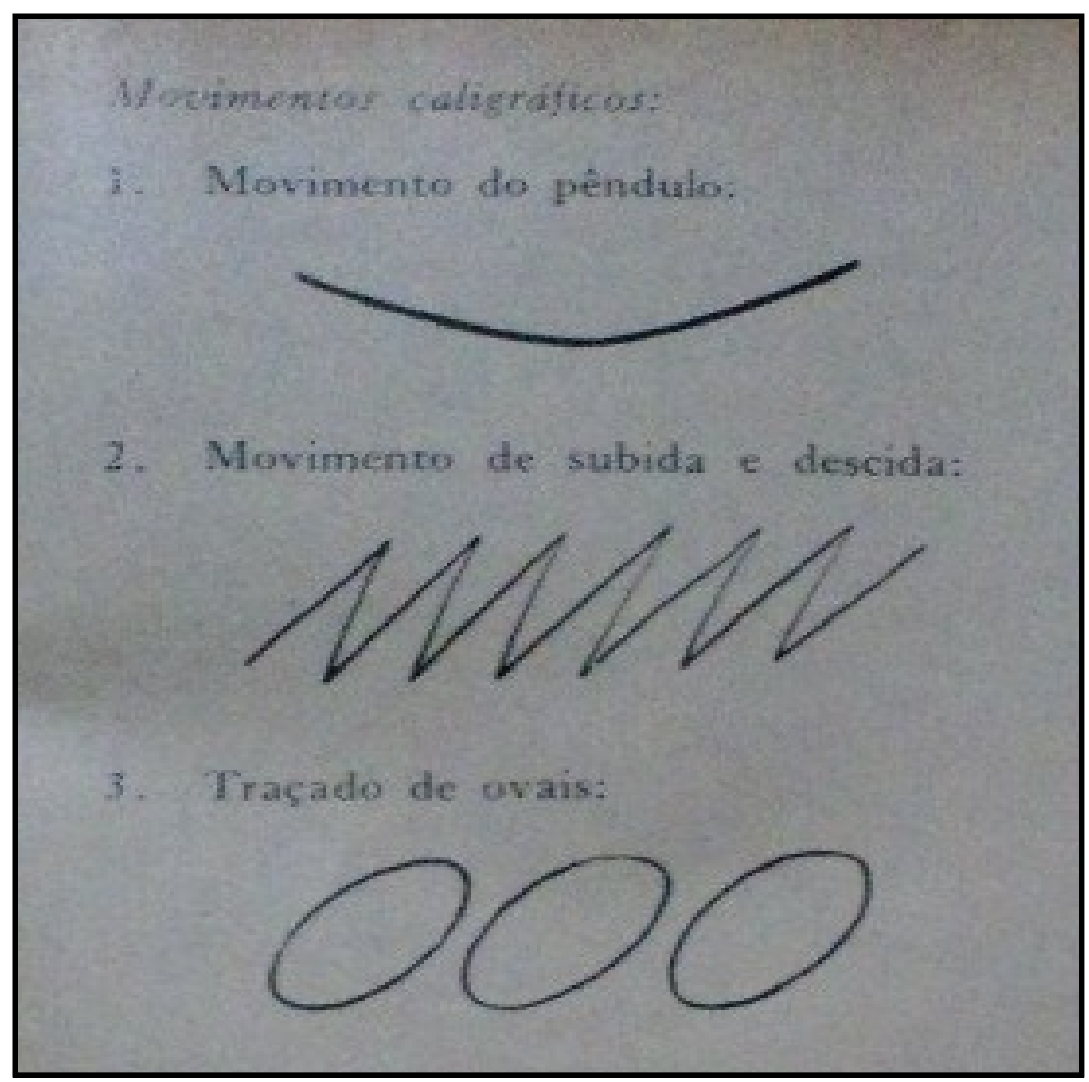

Fonte: Silva, 1956, p. 17.

Deste modo, passa a apresentar as sugestões de atividades com cada tipo de movimento, acompanhadas de música ou contagem para marcação do ritmo, a partir de propostas muito semelhantes (Figuras 3, 5 e 6) àquelas apresentadas por Orminda Marques no livro $A$ escrita na escola primária. Abaixo são destacados exemplos de atividades para cada um desses tipos. 
Figura 9 -

Atividade com o movimento do pêndulo.

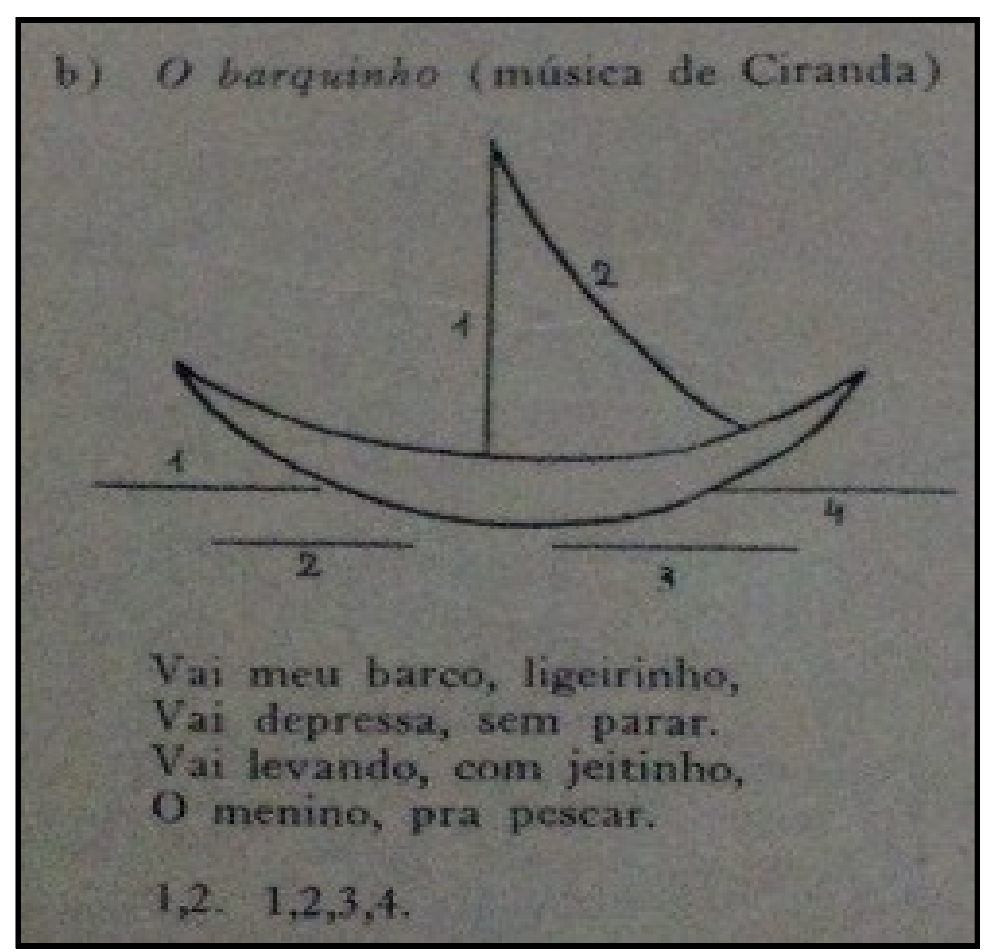

Fonte: Silva, 1956, p. 17.

Figura 10 -

Atividade com o movimento de subida e descida.

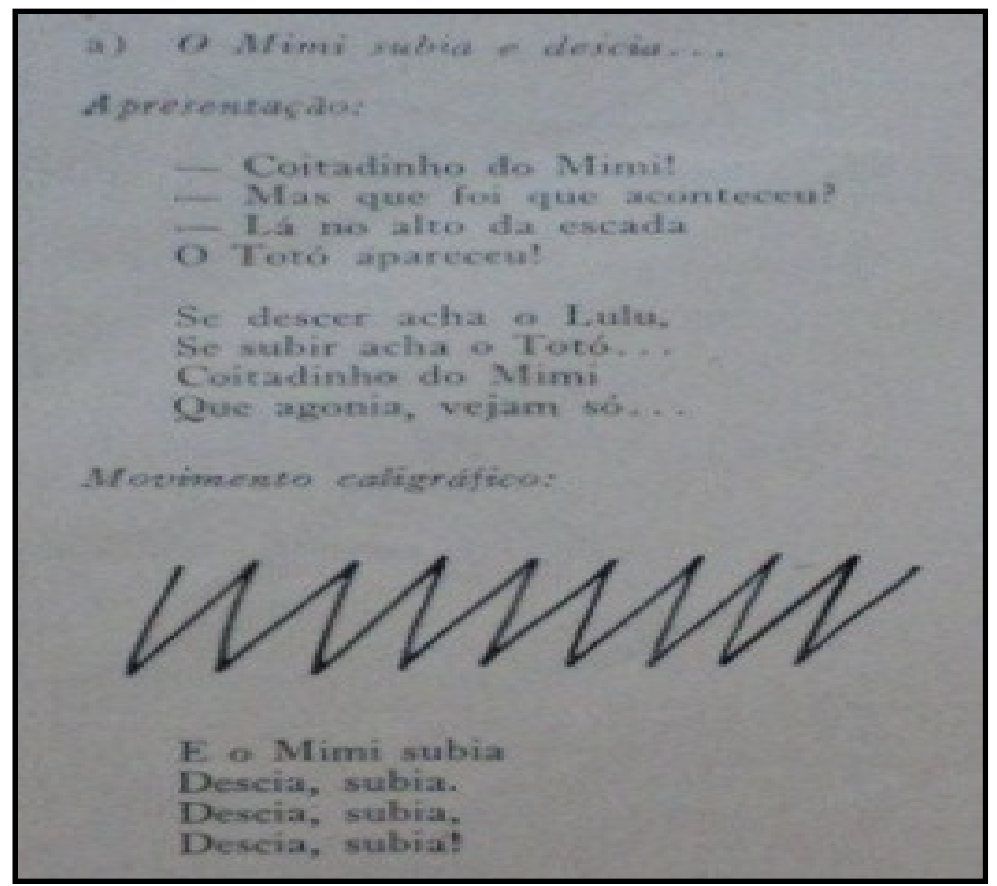

Fonte: Silva, 1956, p. 17. 
Figura 11 -

Atividade com o traçado de ovais.

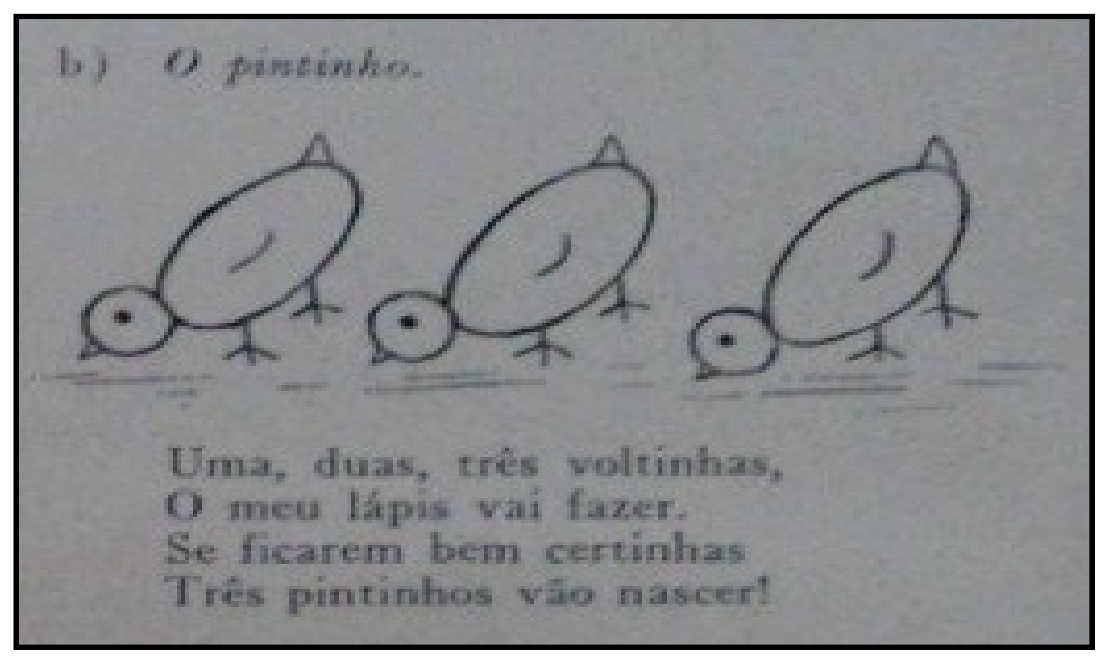

Fonte: Silva, 1956, p. 18.

Na conclusão do artigo a autora reforça a importância da motivação e da busca pelo interesse da criança nas atividades a fim de tornar a escola um espaço agradável e a aprendizagem um objetivo desejável. Nesse sentido, os jogos, as músicas, as brincadeiras, as dramatizações, enfim, a ludicidade, segundo a autora, contribuiria para que tais propósitos fossem alcançados, no que se percebe uma estreita relação do artigo com as proposições de Orminda Marques.

Ainda no número 36 da Revista do Ensino/RS consta o artigo A caligrafia na escola (1956), de Afrânio Coutinho, catedrático do Colégio Pedro II do Rio de Janeiro. O autor inicia este artigo refletindo sobre a decadência geral do ensino, tópico em questão na época, para - que acrescenta "a ausência de atenção ao problema da caligrafia na escola primária" (Coutinho, 1956, p. 69). A discussão segue na direção de apontar o abandono do cuidado especial, anteriormente dado às técnicas fundamentais do ensino: ler, escrever e contar. $O$ autor exemplifica a situação e indica os baixos índices de aprovação no exame de admissão ginasial no Colégio Pedro II, instituição na qual era catedrático. Segundo ele, de 450 candidatos apenas cerca de 70 eram aprovados e entre as falhas mais comuns se destacavam aquelas referentes à escrita, evidenciando uma despreocupação com características de uma boa escrita que tanto orgulhavam os professores em outros tempos: "a caligrafia, a boa apresentação da página escrita, a limpeza, a clareza, a uniformidade, o respeito pelas normas formais do trabalho escrito (margens, espaços, ligações, inclinações regulares, etc.), tudo o que empresta beleza à página, além de torná-la de leitura fácil e rápida" (Coutinho, 1956, p. 69).

A crítica é direcionada aos programas de ensino primário do Distrito Federal, mas também ao fato de poucos Estados brasileiros desenvolverem um programa sistemático direcionado ao ensino da escrita, com exceção, segundo o autor, dos Estados de São Paulo, Minas Gerais e Santa Catarina. Por esse motivo, na opinião de Coutinho, que defendia a 
oferta de aulas especiais de caligrafia, descura-se o aprendizado da escrita no Brasil e se escreve cada vez pior. Sua defesa pelo ensino da caligrafia deve-se ao fato de considerar a escrita um meio de comunicação:

a escrita, sobre ser um meio de expressão individual, é um instrumento de socialização poderoso e indispensável à criança. Sem esquecer que é também um fator de educação artística e de bom-gosto e um meio de disciplina mental. A má escrita revela má higiene do trabalho intelectual, disse Hulliger, citado pela professora Orminda Marques no excelente trabalho sobre o assunto há tempos publicado. (Coutinho, 1956, p. 69)

A hipótese do autor é que a progressiva desvalorização da boa escrita se deve ao fato de, antes, ter havido certo exagero com relação ao aprendizado da caligrafia. Por meio de atividades de cópia o exercício baseava-se, simplesmente, em escrever bonito, sem motivação ou sentido funcional, sendo, portanto, antes um fim que um meio. $O$ autor referese à adoção da letra script, que procurava imitar a letra tipográfica, nos Estados Unidos, por volta do ano de 1921, em decorrência dos avanços da imprensa no período. Segundo ele essa mudança provocou dificuldades para a leitura de bilhetes manuscritos, por exemplo, e afirma que em decorrência disso a escrita cursiva foi reintroduzida no ensino. $O$ autor afirma ainda que isso que ele denomina moda americana foi introduzida também no Brasil e a aponta como responsável pela quebra de padrão na caligrafia escolar em geral.

Nessa direção o autor faz nova referência a Orminda Marques e ressalta que a professora, já em 1935, mostrou em seu estudo, desenvolvido no Distrito Federal, que havia uma decadência na escrita. Segundo ele, desde então, havia indícios de uma sensível piora. Assim como Orminda, Coutinho (1956) afirma que o problema tem sua origem nos professores, que devem dominar a boa escrita para que tenham eficiência no seu ensino. $O$ autor ressalta que a Escola Nova não se opõe a essa técnica e salienta que o ensino moderno não é contrário à boa letra, mas sim a pressa com que se processa a educação.

Em referência à Orminda Marques o autor reforça o valor da escrita como instrumento e meio de comunicação, o que confere grande importância à aquisição dessa habilidade. Conclui, referindo-se e recomendando o livro A escrita na escola primária, com ênfase nos aspectos centrais da obra:

Em seu livrinho tão útil e recomendável a todo o professorado primário do país, conclui a professora Orminda Marques que o ensino da escrita na escola primária é um problema de educação. Após afirmar esse ponto de vista, mostra como o ensino da escrita precisa de sistematização educativa e sentido funcional. Ele deve estar na dependência de motivação e de processos adequados a criar em cada indivíduo um tipo pessoal de escrita, adaptado ao seu ritmo próprio, ao ritmo de sua personalidade. E a seu ver, o melhor sistema é o chamado muscular, em que se combina a boa postura, a boa posição do papel para se obter boa escrita. [...] Esse sistema produz, como o melhor tipo de letra, a cursiva, corrente, inclinada para a direita, ligada, simples, sem talhe. É a mais natural, mais legível, mais rápida, e que proporciona maiores possibilidades de variação individual dentro da socialização. (Coutinho, 1956, p. 68) 
Importa destacar, a partir do excerto acima, a referência e recomendação explícita do autor ao livro de Orminda Marques. O tratamento dado pelo autor à obra, por meio do termo livrinho poderia sugerir ironia ou até mesmo menosprezo, ou ainda, sugerir que embora breve e pequeno, como poderia contemplar matéria tão importante? É assim que toma o livro de Orminda como referência fundamental de seu artigo e considera-o "tão útil e recomendável" (Coutinho, 1956, p. 68), reafirmando seu valor. Além disso, pode-se inferir que ao tratá-lo como um livrinho, o autor estaria sinalizando sua função de manual/guia para o ensino da escrita, impresso que deveria acompanhar o professor.

No número 98 da Revista do Ensino/RS, o artigo Escrita na escola primária (1964), de Adélia de Campos Carregal, professora de Prática de Ensino do Instituto de Educação, aponta, de modo geral, alguns aspectos importantes do ensino da escrita. Importa apresentar as ideias propostas no artigo, pois na sua bibliografia consta o livro $A$ escrita na escola primária, de autoria de Orminda Marques. Além disso, o artigo possui o mesmo título que a obra da autora.

Sem negar o valor da boa letra, o artigo aponta algumas das mudanças que o ensino da escrita sofreu com o passar dos anos: "se antes havia uma preocupação exagerada quanto à perfeição com que a criança deveria traçar letras, hoje já nos interessam mais a clareza, a imaginação e o interesse que a criança demonstra pela expressão escrita" (Carregal, 1964, p. 22).

De acordo com a autora a aprendizagem da escrita é um interesse natural das crianças que chegam às escolas, com o desejo de saber ler e escrever. Assim, é responsabilidade da professora aproveitar essa motivação para atingir o principal objetivo desse ensino que consiste em escrever corretamente, com clareza, precisão, naturalidade e bom gosto. É salientada, ainda, a importância do período preparatório que inicialmente se baseia na imitação, pois a autora lembra que em suas vidas as crianças têm oportunidades de observarem o uso da escrita e sua utilidade, provavelmente tentando imitar os movimentos. Nesse período sugerem-se atividades para a obtenção da coordenação visomotora, como

desenho, pintura, recorte, modelagem e dobradura, alinhavo, enfiação e costura, trabalhos com madeira, quebra-cabeça e exercícios de encaixe, cópia de figuras, traçado de linha acompanhando labirinto, exercícios ritmados no quadro ou no papel, cantando alto, o movimento da esquerda para a direita, que é treinado em exercícios em que se seguem direções e unem-se pontinhos. Também neste período devem as crianças serem levadas a adquirir uma posição correta e confortável para a escrita. (Carregal, 1964, p. 22)

Considerando esse estágio preparatório, a autora distingue três fases no progresso da criança com relação à escrita: 
1) escreve, imitando na carteira, os movimentos que a professora executa no quadro-negro (cópia dirigida).

2) cópia do quadro-negro, porque já memorizou os movimentos que deve executar, mas não a forma da letra em si.

3) escrita independente - já memorizou a forma da letra e o seu traçado escreve então sozinha. (Carregal, 1964, p. 22)

Carregal (1964) ressalta que a repetição, pura e mecânica, não produz efeitos reais a fim de atingir os objetivos do ensino da escrita. Embora o treino sistemático seja necessário, deve ser incentivado por atividades de jogo e brincadeira, para que a criança deseje praticar a escrita. Nesse sentido, as aulas destinadas a esse treino devem ser curtas - 10 a 20 minutos no máximo - e podem ser propostas com trabalho em grupo.

Concluindo o artigo a autora reflete acerca dos debates que envolvem a escolha do tipo de letra que deve ser usado no início da aprendizagem da escrita. Apesar de destacar que os partidários da letra cursiva a defendam por considerarem que a criança quando do ingresso na escola primária já tem maturidade para escrever ligando letras, a autora parece defender o uso da letra script, empregada pelos norte-americanos, indicando que é também empregada na maioria das escolas gaúchas.

Finalmente, no número 123 da Revista do Ensino/RS, o artigo $A$ escrita na escola primária (1969), de Doris Ramos de Mota, Vera Paes Leite e Neusa Junqueira Armellini, professoras do Curso Primário de Aplicação da Escola Anexa de Porto Alegre/RS, consiste no relato da técnica adotada no ensino da escrita com relação à passagem da letra script para a letra cursiva. De acordo com as autoras o trabalho teve início em 1962 e foi fundamentado em estudos de Frank Freeman, Orminda Marques e A. Anderson, tendo como base os postulados relativos à motivação e centralidade do aluno no processo de aprendizagem que caracterizam a Escola Nova. Importa salientar que dentre as referências bibliográficas do artigo em questão, consta o livro $A$ escrita na escola primária, de Orminda Marques. À primeira vista destaca-se o caráter diferenciado da publicação do artigo no periódico, apresentado em colunas, com subtítulos, quadros com destaques, como pode ser visto na imagem a seguir. 
Figura 12 -

Página do artigo A escrita na escola primária (1969).

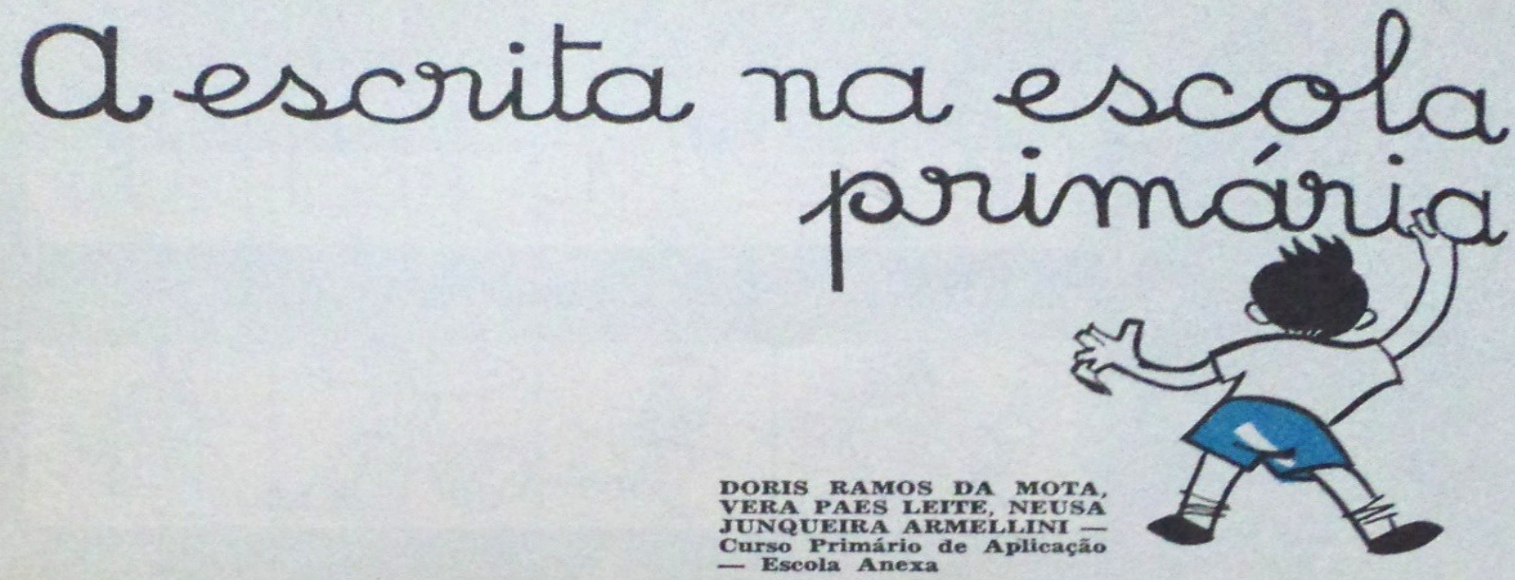

I - INTRODUCGÃO

O presente trabalho relata a técnica que temos adotado no ensino da escrita, no que se refere à passagem da letra "script" para a letra cursiva. Foi iniciado em 1962, fundamentando-se em estudos realizados nos autores Frank N. Freeman, Orminda Marques e A. Anderson.

II - PRINCIPIOS ORIENTADORES DA APRENDIZAGEM PRESENTES DURANTE A REALIZAÇAO DO TRABALHO

- Tôda a aprendizagem é modificação de comportamento.

- Tôda a aprendizagem é auto-aprendizagem.

- A aprendizagem é um processo global, cumulativo, único e individual.

- Tóda a aprendizagem é motivada.

- Toda a aprendizagem envolve atividade por parte daquele que

- Cada indivíduo aprende segundo seu ritmo próprio de aprendizagem.

- Tóda a aprendizagem melhor se efetiva quando se realiza em pequenas etapas. posta.

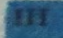

A escrita é um instrumento necessário para que o aluno possa participar efetivamente do mundo de hoje. E ela uma técnica valiosa, porque possibilita o enriquecimento das experiências de aprendizagem da criança, promovendo a sua autoexpressão e concorrendo para o seu processo de socialização.

Dentro do contexto da escrita ocupa a caligrafia papel relevante. O ensino da caligrafia, nas escolas de nossos dias, se apresenta com um caŕter fumcional, fazendo parte ativa de todo o processo de aprendizagem.

A caligrafia visa atender às atuais exigências de clareza, legibilidade $e$ rapidez, justificandio-se a sua presença no currículo da Escola Primária, e exigindo especial atençẩo por parte do professor.

IV - O PORQUE DA REALTZACÃO DO NOSSO TRABAL.HO

Nossos alunos iniciam sua aprendizagem de escrita, utilizando-se da letra script. Justifica tal posiçáa o fato da aprendizagem do "script reduzir o forco ficico da crianca. reduzir oño a complexos porque náo apresenta os complexiva. movimentos e ligaçóes da cursiva.

Ao chegarem ao nivel de $3 .^{\circ}$ e $4^{\circ}$

Fonte: Mota; Leite; Armellini, 1969, p. 16.

No texto, as autoras tratam a escrita como um instrumento essencial para que as crianças possam participar da vida social e enfatizam sua importância como meio de comunicação e expressão. Nesse contexto, a caligrafia exerce papel relevante, pois "visa atender às exigências de clareza, legibilidade e rapidez, justificando a sua presença no currículo da escola primária, e exigindo especial atenção por parte do professor" (Mota; Leite; Armellini, 1969, p. 16). Segundo as autoras, nas escolas a caligrafia constitui parte ativa de todo o processo de aprendizagem uma vez que apresenta o caráter funcional. 
A justificativa do trabalho desenvolvido pelas autoras e apresentado neste artigo se deve à utilização da letra script no início da aprendizagem da escrita, pois esta não exige o esforço físico que, por sua vez, é exigido nos movimentos da letra cursiva. No entanto, o ensino da letra cursiva se faz necessário, pois, de acordo com as autoras, há uma imposição da família e da sociedade para seu uso, além de um grande interesse por parte das próprias crianças em aprender esse tipo de escrita. Nesse sentido, as autoras desenvolvem uma técnica adaptada ao contexto, com base nos autores já mencionados, e que consiste na passagem, no $3^{\circ}$ ou $4^{\circ}$ ano do ensino primário, da letra script para a letra cursiva.

Portanto, segundo as autoras, quanto aos alunos, os objetivos a partir desse trabalho consistiam em:

- Desenvolver a habilidade de escrever a letra cursiva de maneira clara, legível e rápida;

- Dominar a técnica da escrita da letra cursiva: aquisição de tamanho normal da letra; aperfeiçoamento da forma, uniformidade da inclinação e do espaçamento; maior desembaraço de movimentos e leveza de traços;

- Formar atitudes higiênicas na realização dos trabalhos escritos: posição do corpo, do lápis, inclinação do papel;

- Formar uma atitude de disponibilidade, gosto e interesse pela apresentação estética dos trabalhos escritos: margem, parágrafo, colocação de títulos, disposição elegante;

- Desenvolver a capacidade de orientar a sua própria aprendizagem, esforçando-se por atingir os objetivos propostos, através de uma positiva autocompetição. (Mota; Leite; Armellini, 1969, p. 17)

O desenvolvimento do trabalho abarcava a preparação do professor, por meio de fundamentação em bibliografia especializada, a elaboração de um plano de ação, a realização de exercícios específicos com vistas à obtenção do domínio dos movimentos e do traçado das letras e a preparação cuidadosa dos materiais para trabalho com os alunos. Isto porque o ensino da escrita estava baseado, em especial na fase inicial, na imitação, sendo imprescindível que a professora escrevesse bem, corretamente e de forma legível, servindo como exemplo e estímulo para que a criança desenvolvesse uma boa escrita.

$O$ procedimento relativo à realização do trabalho da criança é apresentado pelas autoras subdividido em seis momentos, minuciosamente explicados. $O$ primeiro consiste no planejamento da atividade a partir dos interesses dos alunos e a apresentação de algumas normas, tais como a conservação do lápis bem apontado, o cuidado com a posição do corpo, do papel e do lápis e a recomendação de trabalhar com calma, atenção e disposição. Em seguida é proposta uma série de atividades graduadas, que correspondem aos exercícios preparatórios recomendados por Orminda Marques, seguindo o roteiro já apresentado nos outros artigos anteriormente tratados: traçado pela professora no quadro, realização do movimento no ar com a marcação do ritmo acompanhada de música, reprodução do movimento no quadro e no ar por parte das crianças - duas a duas -, realização do movimento várias vezes, pelas crianças, em folhas grandes com giz ou lápis coloridos. 
Após esse trabalho inicial, segundo as autoras, a professora deveria escrever no quadro palavras em script, cobrindo-as e ligando as letras com giz colorido, evidenciando assim as relações entre a letra script e a cursiva. A partir disso a criança perceberia que a letra deve ser clara e legível e o traçado e o movimento uniformes e corretos. Ademais, que o lápis só deve ser afastado do papel depois de escrita toda a palavra, acrescentando-se os pingos, traços e acentos. Perceberia, por fim, aspectos com relação ao tamanho das letras maiúsculas e minúsculas e o espaço que devem ocupar nas linhas. As autoras, ainda, sugeriam que tais normas fossem escritas em um cartaz a ser afixado na sala de aula.

Num quarto momento o procedimento adotado nos exercícios preparatórios deveria ser desenvolvido com o traçado das letras, utilizando, inicialmente, a correspondência entre a letra script e a cursiva, passando para a repetição de uma mesma letra no quadro para que a criança sentisse o ritmo do movimento e das ligações. Partindo do traçado no ar, passando pelas folhas grandes com giz e chegando às folhas mimeografadas com um modelo a ser copiado, as autoras sugeriam que conforme as letras fossem sendo trabalhadas, um trabalho similar com sílabas fosse orientado. Outra sugestão consistia na produção de fichas com cada letra - maiúscula e minúscula - para a organização de um cartaz com o alfabeto a ser afixado na sala para futuras consultas. Esse trabalho, realizado com as letras agrupadas com base nos movimentos do seu traçado, seguia a mesma organização proposta por Orminda Marques no livro $A$ escrita na escola primária, figura 4.

Figura 13 -

Grupos de letras por traçado.

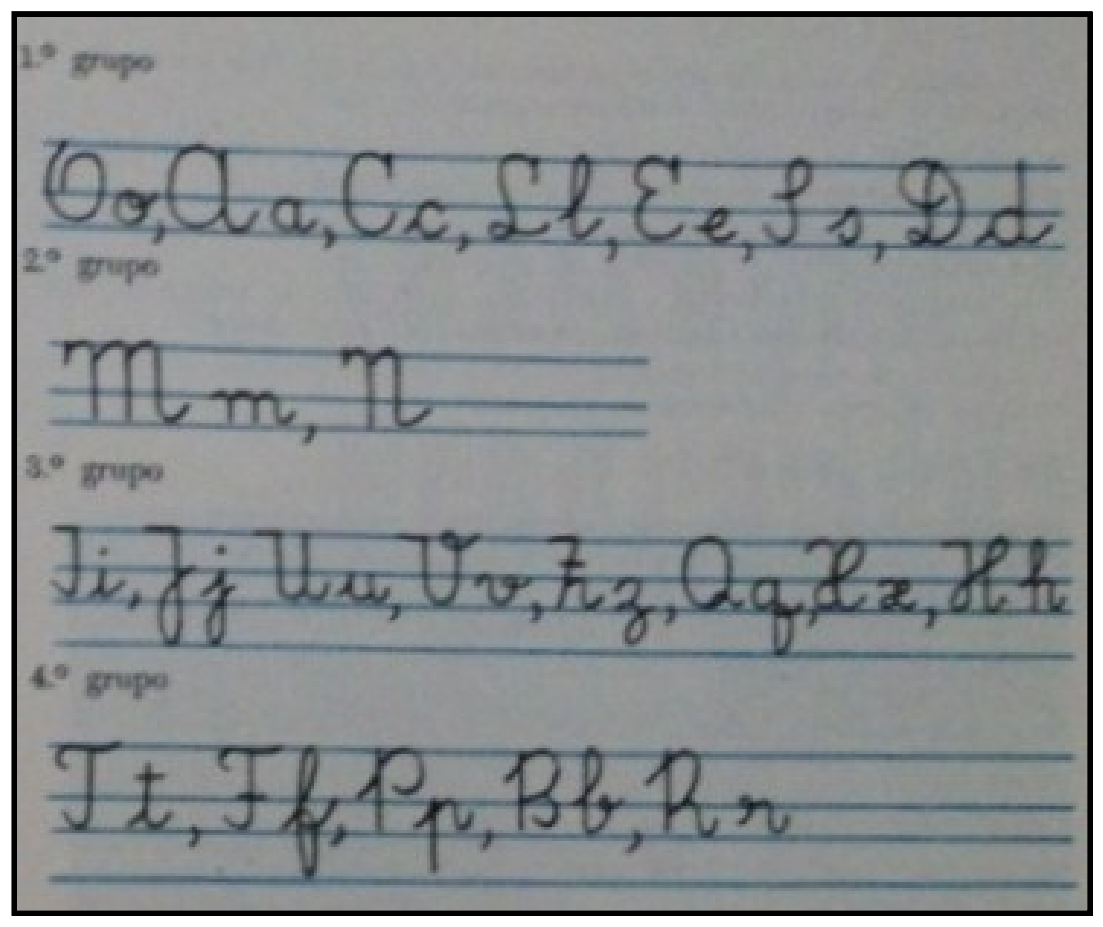

Fonte: Mota; Leite; Armellini, 1969, p. 16. 
Conforme as crianças dominassem o traçado das letras passariam a escrever palavras e frases, chegando, por fim a escrever com clareza, desembaraço e certa rapidez, a utilizar a escrita cursiva de modo funcional em situações como escrita do nome em placa a ser afixada na classe, escrita da data, do plano do dia, de frases ou pequenos textos até chegar à escrita de todos os trabalhos desenvolvidos em aula. Entretanto, as autoras ressaltavam que as atividades de caligrafia deveriam ser dosadas, pois consideravam que a qualidade da escrita é mais importante do que a quantidade.

$\mathrm{Na}$ conclusão do artigo as autoras apontam alguns princípios orientadores da técnica, tais como: alertar as crianças para que sigam as normas preestabelecidas, levando-as a avaliar seus trabalhos, orientar e verificar o trabalho de traçado das letras individualmente, considerando o ritmo de cada criança, daí que o aluno não deveria ser apressado e a professora deveria estimulá-lo e incentivá-lo a progredir. Sugeriam, inclusive, que a professora organizasse uma coleção de materiais das crianças para que elas mesmas pudessem avaliar seus avanços na aprendizagem da escrita cursiva.

\section{Considerações finais}

A leitura do material acima descrito possibilita afirmar que, seguindo o propósito da Revista do Ensino/RS, os artigos nela publicados acerca do ensino da escrita, de modo geral, têm como finalidade divulgar práticas e experiências desenvolvidas nesse âmbito, com vistas à formação docente. Reflexões sobre a decadência da qualidade da escrita, o papel do professor, o melhor tipo de letra, sugestões de exercícios e atividades são uma constante nos diferentes números deste periódico.

Com relação às referências ao estudo desenvolvido por Orminda Marques sobre o ensino da escrita na escola primária, destacam-se as aproximações com o sistema muscular, por meio de um trabalho que leve em consideração o ritmo, a utilização de músicas, a contagem e os jogos para a aquisição dos movimentos da escrita, além das semelhanças entre os objetivos a serem alcançados no ensino da escrita e o modo de verificar o progresso desse trabalho.

O ideário escolanovista é reforçado nas propostas direcionadas à prática pedagógica dos professores leitores da Revista do Ensino/RS. Como foi afirmado antes, os artigos desta revista visavam à renovação das práticas educativas. Embora em seus artigos o periódico se reporte a proposições elaboradas nos anos 1930 pela professora Orminda Marques, considerando neste caso específico o ensino da escrita, vale lembrar que este tipo de impresso aspirava a um caráter de novidade e de atualidade. Reafirma-se, então, residir aí um indício da persistência no tempo das ideias, das proposições pedagógicas práticas e das recomendações de Orminda Marques, tomadas como atuais e inovadoras décadas após sua elaboração e primeira publicação.

Além disso é visível, nos artigos destacados da Revista do Ensino/Rio Grande do Sul, a ênfase dada a seus autores. Trata-se de autores que são professores, que com esse título assumem um caráter de autoridades nos assuntos que abordam, mas também evidenciam uma contribuição do movimento da Escola Nova, ou seja, a atuação do professorado no desenvolvimento de estudos e pesquisas, contribuindo para a valorização da educação como 
ciência. Há, ainda, a indicação da instituição a qual cada autor ou autora pertence e a preocupação em apresentar relatos de experiências como exemplos emblemáticos a seus leitores.

Com relação à apresentação tipográfica deste material é relevante destacar alguns aspectos que são característicos dos periódicos da época. A diagramação do texto neste suporte é diferente do suporte livro. O texto é disposto em colunas, apresenta quadros com destaques, há a utilização de cores e imagens em alguns artigos. Estes recursos podem ser tratados como protocolos de leitura, ou seja, "estratégias usadas pelo próprio texto, que deseja produzir efeitos, ditar uma postura, obrigar o leitor" (Cavallo; Chartier, 1998, p. 38), pois tais recursos guiam o leitor ao enfatizarem palavras e ideias que o autor considera mais significativas à compreensão do texto.

Ainda sob esse aspecto cumpre salientar a importância do suporte na relação da leitura com um texto. De acordo com Chartier (1998), esta relação "depende, é claro, do texto lido, mas depende também do leitor, de suas competências e práticas, e da forma na qual ele encontra o texto lido ou ouvido" (p. 152). Nesse sentido, é pertinente refletir sobre o texto publicado em diferentes suportes, especificamente tratando da análise das repercussões da obra de Orminda Marques.

Levando em conta o interesse de propagação do ideário da Escola Nova junto ao professorado, e a utilização, à época, dos impressos para este fim, importa considerar as diferentes formas que os impressos assumem e as diferentes formas de recepção dos textos pedagógicos. Em outras palavras, a leitura de um texto é diferente dependendo do suporte no qual ele é oferecido ao leitor. A leitura de um texto em um manual pedagógico, por exemplo, poderia ser associada ao estudo aprofundado do tema e à formação do professor, enquanto a leitura de um texto em um periódico, supostamente mais objetiva e sintética, parece mais acessível e associada ao cotidiano pedagógico. Assim, tomando como texto comum às proposições de Orminda Marques, deve-se considerar os diferentes modos de ler este texto nos diferentes suportes em que se apresenta aos leitores, o que justifica o mérito de um estudo de suas repercussões no tempo, dado a ler em diferentes materialidades e em diferentes formulações, apropriado por autores e editores.

Uma história da relação prática instaurada pelos professores diante desses textos é objeto de estudos que ainda estão por serem feitos. Mas o reconhecimento de sua proliferação em diferentes modalidades e materialidades é um passo importante.

\section{Referências}

BASTOS, Maria Helena Camara. A Revista do Ensino do Rio Grande do Sul (1939-1942): o novo e o nacional em revista. Pelotas: Seiva, 2005.

BRAGA, Rosa Maria de Souza. Caligrafia em pauta: a legitimação de Orminda Marques no campo educacional. Rio de Janeiro: Uerj, 2008. 181f. Dissertação (mestrado em Educação). Universidade do Estado do Rio de Janeiro, Programa de Pós-graduação em Educação.

CARREGAL, Adélia de Campos. Escrita na escola primária. In: Revista do Ensino. Porto Alegre: SEC/RS, n. 98, 1964, p. 22-23. 
CAVALLO, Guglielmo; CHARTIER, Roger. Introdução. In: CAVALLO, Guglielmo; CHARTIER, Roger. História da leitura no mundo ocidental. São Paulo: Ática, 1998, p. 5-40.

CHARTIER, Roger. A aventura do livro: do leitor ao navegador. São Paulo: Unesp, 1998.

COUTINHO, Afrânio. A caligrafia na escola. In: Revista do Ensino. Porto Alegre: SEC/RS, n. 36, 1956, p. 69-68.

LOURENÇO FILHO, Manuel Bergström. A escrita e a escola renovada. In: MARQUES, Orminda Isabel. A escrita na escola primária. São Paulo: Melhoramentos, 1936, p. 3-6.

MARQUES, Orminda Isabel. A escrita na escola primária. São Paulo: Melhoramentos, 1936.

MOTA, Doris Ramos da; LEITE, Vera Paes; ARMELLINI, Neusa Junqueira. A escrita na escola primária. Revista do Ensino. Porto Alegre: SEC/RS, n. 123, 1969, p. 16-20/25.

SILVA, Arlette Pinto de Oliveira e. Preparando para ler. Revista do Ensino. Porto Alegre: SEC/RS, n. 36, 1956, p. 16-19.

CAROLINA MONTEIRO é licenciada em Pedagogia, mestre em Educação e estudante do curso de doutorado em Educação no Programa de Pós-Graduação em Educação da Universidade Federal do Rio Grande do Sul.

Endereço: Rua Botafogo, 1246/202 - 90150-052 - Porto Alegre - RS - Brasil.

E-mail: carolinamonteiro7@yahoo.com.br.

Recebido em 24 de março de 2015.

Aceito em 18 de outubro de 2015. 